\title{
Characterization of Bacillus anthracis spores isolates from soil by biochemical and multiplex PCR analysis
}

F. Vahedi, ${ }^{1,2}$ Gh. Moazeni Jula, ${ }^{3}$ M. Kianizadeh ${ }^{2}$ and M. Mahmoudi ${ }^{1}$

$$
\begin{aligned}
& \text { التعرف على خصائص أبواغ العصوية الجمرية المستفرَدة من التربة بالتحليل الكيميائي الحيوي وتفاعل } \\
& \text { البوليميراز السلسلي المتكرر }
\end{aligned}
$$

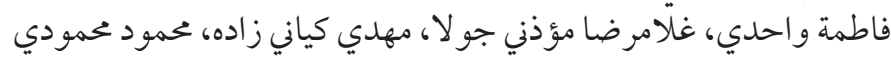

ABSTRACT Outbreaks of Bacillus anthracis in animals are repeatedly reported in the Islamic Republic of Iran. In this study soil samples were analysed from endemic regions of the country, and $B$. anthracis isolates were identified by classical bacteriological and biochemical methods. A multiplex polymerase chain reaction (PCR) assay was also developed as an alternative for identification of isolates, and was shown to be a rapid, sensitive and specific diagnostic assay. The results confirmed that 25 samples contained $B$. anthracis, of which 9 were virulent for mice and guinea pigs. This study suggests that multiplex PCR can be used as a reliable alternative for the detection of $B$. anthracis spores.

\footnotetext{
Caractérisation d'isolats de Bacillus anthracis provenant du sol par analyse biochimique et PCR multiplex

RÉSUMÉ Des épidémies de Bacillus anthracis chez les animaux sont souvent signalées en République islamique d'Iran. Dans cette étude, des échantillons de sol venant de régions endémiques du pays ont été analysés et des isolats de $B$. anthracis ont été identifiés grâce aux méthodes bactériologiques et biochimiques classiques. Un test d'amplification en chaîne par polymérase (PCR) multiplex a également été mis au point pour identifier les isolats, et il s'est avéré que cette autre solution constituait un test diagnostique rapide, sensible et précis. Les résultats ont confirmé que 25 échantillons contenaient $B$. anthracis, et que 9 souches étaient virulentes pour les souris et les cobayes. Cette étude suggère que la PCR multiplex peut être utilisée comme solution de remplacement fiable aux fins de la détection de spores de $B$. anthracis.
}

\footnotetext{
${ }^{1}$ Immunology Research Centre, Mashhad University of Medical Sciences, Mashhad, Islamic Republic of Iran (Correspondence to F. Vahedi: vahedif@yahoo.com).

${ }^{2}$ Razi Vaccine and Serum Research Institute, Mashhad, Islamic Republic of Iran.

${ }^{3}$ Razi Vaccine and Serum Research Institute, Karaj, Islamic Republic of Iran.

Received: 26/06/05; accepted: 13/08/06
}

المجلة الصحية لشرق المتوسط، منظمة الصحة العالمية، المجلد الخامس عشر، العدد (، 9 ·. 


\section{Introduction}

Bacillus anthracis is a gram-positive, aerobic, spore-forming bacterium that causes anthrax in mammals [1]. B. anthracis spores are very resistant to various conditions. The spores can survive for many years in soil. This long survival is important in epidemiological studies and in planning for control and prevention of anthrax. The success of the attenuated Sterne veterinary vaccine in 1930 resulted in a global reduction of anthrax cases in livestock in response to national vaccination programmes.

Unfortunately there are still regions where anthrax is endemic. The Islamic Republic of Iran is an endemic region with many reported outbreaks in recent years. Outbreaks occur not only in wild animals [2] but also in domestic animals [3]. Animals become infected after coming into contact with soil-borne spores when grazing. Humans become infected after contact with infected animals or their contaminated products [4]. Surveillance and monitoring of anthrax is therefore a focus in public health.

$B$. anthracis is closely related to several species, including $B$. cereus and $B$. thurengiensis $[5,6]$. The virulent strains of $B$. anthracis harbour 2 virulent plasmids, toxin-encoding plasmid pX01 (181.7 kb) $[7,8]$ and plasmid pX02 (96.2 kb) which codes for the capsule [9]. The current routine laboratory diagnostic method for $B$. anthracis is microbiological analysis $[4,10]$. Avirulent $B$. anthracis strains lack pX01 and pX02 and cannot be distinguished from other related species with these time-consuming microbiological analyses $[11,12]$. Therefore, development of a specific and rapid method for detection of $B$. anthracis is required.
In this study soil samples were collected from regions of the Islamic Republic of Iran where there are repeated reports of outbreaks of $B$. anthracis. These samples were analysed for the presence of $B$. anthracis using routine assay and a multiplex polymerase chain reaction (PCR) assay that was established in-house (at the Razi Vaccine and Serum Research Institute, Mashhad, Islamic Republic of Iran).

\section{Methods}

\section{Soil sampling}

Soil samples were randomly collected from anthrax-endemic regions of Isfahan province in the central part of the Islamic Republic of Iran. A total of 60 specimens were collected. In each collection, approximately $500 \mathrm{~g}$ of the topsoil to a maximum depth of $20 \mathrm{~cm}$ were included and transferred to labelled bags.

\section{Spore extraction and bacteria identification}

An overnight incubated soil suspension in sterile phosphate-buffered saline (PBS) was passed through a $0.45 \mu \mathrm{m}$ filter and the deposit was suspended in sterile PBS. The aliquot was heated at $65^{\circ} \mathrm{C}$ to destroy vegetative cells and activate the spores. Then the suspension was centrifuged and the resuspended pellet was streaked onto duplicate plates of PLET agar (a selective media for $B$. anthracis) and blood agar media. One set of cultured plates was incubated at $37{ }^{\circ} \mathrm{C}$ and the other at $40{ }^{\circ} \mathrm{C}$, both aerobically. Colonies emerging were examined for morphological and cultural features of $B$. anthracis at the end of 24-48 hours of incubation.

\section{Biochemical and biological analysis}

The colonies identified as $B$. anthracis were selected and further biochemical tests were 


\begin{tabular}{|c|c|c|c|}
\hline Primer & Sequence (5-3) & Expected size & Target gene \\
\hline Bac F & AAT GAT AGC TCC TAC ATT TGG AG & \multirow{2}{*}{$150 \mathrm{bp}$} & \multirow{2}{*}{ Chromosome } \\
\hline Bac R & TTA ATT CAC TTG CAA CTG ATG GG & & \\
\hline PA F & CGA AAA GGT TAC AGG ACG G & \multirow{2}{*}{$330 \mathrm{bp}$} & \multirow{2}{*}{ pX01 } \\
\hline PA R & CAA GTT CTT TCC CCT GCT A & & \\
\hline Cap F & GTA CCT GGT TAT TTA GCA CTC & \multirow{2}{*}{$209 \mathrm{bp}$} & \multirow{2}{*}{ pX02 } \\
\hline Cap R & ATC TCA AAT GGC ATA ACA GG & & \\
\hline
\end{tabular}

$B a c=B$. anthracis chromosome; $P A=$ protective antigen; Cap = capsule.

conducted according to classical bacteriological methods [13]. The saline suspension containing different numbers of spores was injected subcutaneously to mice and guinea pigs to evaluate the lethality of the isolates $[14,15]$.

\section{Total DNA extraction}

Bacterial isolates were cultured on blood agar plates and then 1 colony was picked and resuspended in normal saline. All of the bacterial suspensions were inactivated in boiling water for 15 minutes. A simple and rapid method was used for total DNA extraction. Briefly, $200 \mu \mathrm{L}$ of inactivated bacterial cultures were vortexed vigorously and then frozen in liquid nitrogen. The samples were thawed and vortexed again. These steps were repeated 3 times and then the samples were centrifuged at $12000 \times \mathrm{g}$ for 1 minute. Finally, the obtained supernatants were used as DNA source directly.

\section{Primers}

Three pairs of primers were designed according to $B$. anthracis sequences deposited in the GenBank ${ }^{\circledR}$ database. The primers were synthesised by TIB MOLBIOL (Berlin, Germany). The primers that were used for specific amplification of $B$. anthracis chromosome (Bac) were designed on the basis of the previously published sequences [16]. Protective antigen (PA) and capsule (Cap) primers were used to confirm the presence of plasmids $\mathrm{pX} 01$ and $\mathrm{pX} 02$ respectively. These primers were confirmed to be specific for targets based on the previous studies and after comparison with $B$. anthracis sequences from the database of the National Centre for Biotechnology Information using the BLAST network server [17-20]. Sequences of these oligonucleotide primers are shown in Table 1.

\section{Multiplex PCR}

In order to optimize the PCR reaction, we first set each primer at a concentration of 5 pmol in separate amplification reactions. Subsequently we optimized the multiplex PCR reactions.

The final optimized PCR mixtures $(25 \mu \mathrm{L})$ consisted of: $200 \mu \mathrm{M}$ each of dATP, dCTP, dGTP and dTTP, $4 \mathrm{mM}$ $\mathrm{MgCl}_{2}, 5$ pmol of each primer, and $2.5 \mu \mathrm{L}$ of $10 \times$ reaction buffer $(100 \mathrm{mM}$ $\left(\mathrm{NH}_{4}\right) 2 \mathrm{SO}_{4}, 200 \mathrm{mM}$ Tris- $\mathrm{HCl}(\mathrm{pH} 8.8)$, $1 \%$ Triton $\mathrm{X}-100,100 \mathrm{mM} \mathrm{KCl}, 1 \mathrm{mg} / \mathrm{mL}$ BSA) and 0.05 pg of DNA extraction in $3 \mu \mathrm{L}$ doubled-distilled water. PCR analysis was performed under the following conditions using the Techne 1600 (Techne, Cambridge, United Kingdom): 1× $\left(94{ }^{\circ} \mathrm{C}\right.$ for $\left.5 \mathrm{~min}\right), 35 \times\left(94{ }^{\circ} \mathrm{C}\right.$ for $50 \mathrm{~s}$ followed by $58{ }^{\circ} \mathrm{C}$ for $50 \mathrm{~s}$ and $72{ }^{\circ} \mathrm{C}$ for $50 \mathrm{~s}), 1 \times\left(72^{\circ} \mathrm{C}\right.$ for $\left.1 \mathrm{~min}\right)$, cool to $25^{\circ} \mathrm{C}$.

المجلة الصحية لشرق المتوسط، منظمة الصحة العالمية، المجلد الخامس عشر، العدد (، 9 +. 
Serial dilutions of extracted DNA were used as the template for multiplex PCR. The specificity of optimized multiplex PCR was tested using archived samples of the Bacillus genus: B. subtilis, B. cereus, $B$. thuringiensis and $B$. mycoides.

\section{Analysis and detection of amplified DNA (PCR products)}

Finally, $5 \mu \mathrm{L}$ of each amplification reaction was analysed on $2 \% \mathrm{w} / \mathrm{v}$ agarose in Tris-acetate-EDTA buffer containing $0.5 \mu \mathrm{g} / \mathrm{mL}$ ethidium bromide. A $50 \mathrm{bp}$ marker (Fermentas, Lithuania) was also included on every gel. The gel was analysed under ultraviolet illumination.

\section{Results}

The presence of $B$. anthracis in collected soil samples was determined and analysed morphologically and biochemically. A total of 25 samples were positive: 11 of these positive samples displayed rods with capsules by Giemsa staining, 9 of them were lethal to mice and guinea pigs and 8 of the samples did not produce toxin or capsule. Table 2 summarizes the results.

Our optimized multiplex PCR assay was able to successfully amplify 3 fragments of the expected sizes from extracted DNA of positive controls. Three fragments of 152 bp (Bac), 209 bp (Cap) and 330 bp (PA) reflected the presence of $B$. anthracis chromosome, capsule and toxin respectively. The sensitivity of this assay was tested by serial dilution of genomic DNA from the $B$. anthracis positive control. A minimum of $0.05 \mathrm{pg}$ of total DNA was sufficient to be used as a template in the PCR. The multiplex PCR proved to be very specific for $B$. anthracis and did not result in false positives with any other bacteria. Therefore, the specificity for this protocol was calculated at $100 \%$. The presence of $B$. anthracis was confirmed in all 25 samples by amplification of the 152 bp Bac DNA fragment. Cap and PA fragments were amplified in 12 and 14 samples respectively (Figures 1, 2 and 3).

\section{Discussion}

Anthrax is still one of the most serious infectious diseases in animals and man because of its highly resistant spores and wide distribution. Approximately $95 \%$ of anthrax cases in humans result from exposure to infected soil or animals, through skin lesions. Therefore, continuous surveillance for anthrax is essential to prevent this threat, especially in the Islamic Republic of Iran, where there are a number of endemic regions. During a 1945 outbreak in the Islamic Republic of Iran, 1 million sheep died, one of the largest anthrax epizootics in herbivores reported [5]. In recent years controlling the disease through vaccination has reduced anthrax cases in the country.

The survival of anthrax spores in soil is an important factor, especially in animal outbreaks. A classic case is the experience at Gruinard Island, Scotland, during the Second World War, where spores persisted and remained viable for 36 years. Decontamination of the island was completed in stages, beginning in 1979 and ending in 1987, when the island was finally declared fully decontaminated. There have been similar experiences in northern Canada and south Sudan $[18,19]$. Specific soil parameters, such as alkaline $\mathrm{pH}$, adequate nitrogen, calcium and organic material, are required in conjunction with extreme weather changes to undergo a vegetative cycle and cause disease in grazing animals, producing the occasional outbreaks [20].

In our study 25 isolates of $B$. anthracis from infected regions of the Islamic Republic of Iran were obtained, of which 9 were virulent in guinea pigs and mice. Bacillus bacteria are notable for their 
Table 2 Results of screening of isolated Bacillus anthracis strains: success in detection by in-house polymerase chain reaction (PCR) assay or traditional methods

\begin{tabular}{|c|c|c|c|c|c|}
\hline \multirow{2}{*}{$\begin{array}{l}\text { Test } \\
\text { number }\end{array}$} & \multirow{2}{*}{$\begin{array}{l}\text { Presence of } \\
\text { B. anthracis } \\
\text { chromosome } \\
\text { by PCR }\end{array}$} & \multicolumn{2}{|c|}{ Capsule presence } & \multicolumn{2}{|c|}{ Toxin production } \\
\hline & & By PCR & $\begin{array}{l}\text { By Giemsa } \\
\text { staining }\end{array}$ & By PCR & $\begin{array}{l}\text { Lethality } \\
\text { in mice or } \\
\text { guinea pigs }\end{array}$ \\
\hline$\overline{1}$ & + & + & + & - & - \\
\hline 2 & + & - & - & - & - \\
\hline 3 & + & + & + & + & + \\
\hline 4 & + & - & - & - & - \\
\hline 5 & + & + & + & + & + \\
\hline 6 & + & - & - & + & - \\
\hline 7 & + & + & + & + & + \\
\hline 8 & + & - & - & - & - \\
\hline 9 & + & + & + & + & + \\
\hline 10 & + & + & + & + & + \\
\hline 11 & + & - & - & + & - \\
\hline 12 & + & - & - & + & - \\
\hline 13 & + & - & - & + & - \\
\hline 14 & + & + & + & + & + \\
\hline 15 & + & + & + & + & + \\
\hline 16 & + & - & - & - & - \\
\hline 17 & + & + & + & + & + \\
\hline 18 & + & - & - & + & - \\
\hline 19 & + & - & - & - & - \\
\hline 20 & + & + & - & - & - \\
\hline 21 & + & + & + & - & - \\
\hline 22 & + & + & + & + & + \\
\hline 23 & + & - & - & - & - \\
\hline 24 & + & - & - & - & - \\
\hline 25 & + & - & - & - & - \\
\hline
\end{tabular}

phenotypic similarities. The species can be distinguished on the basis of time-consuming biochemical and microbiological analysis [6]. The main feature used to distinguish $B$. anthracis from other closely related Bacillus spp. is the presence of 2 virulent plasmids $\mathrm{pX} 01$ and $\mathrm{pX} 02$. The use of PCR as a highly sensitive, specific and rapid test for identification has been reported. Virulent genes on these plasmids have been used as markers to detect $B$. anthracis using PCR assay [21,22]. Avirulent strains 


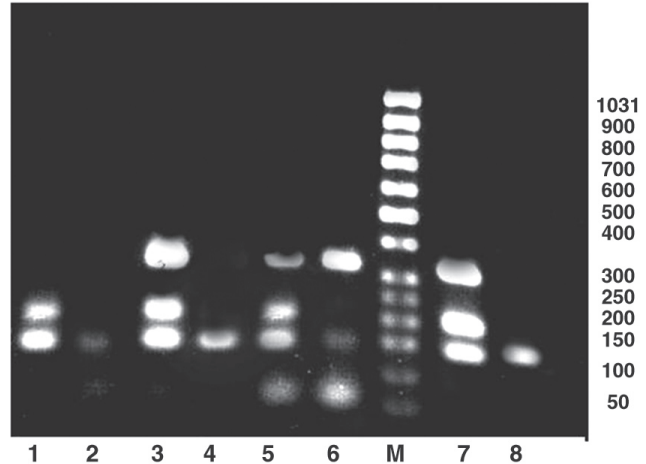

Figure 1 Agarose gel electrophoresis of multiplex polymerase chain reaction products of Bacillus anthracis isolates (Bac $=B$. anthracis chromosome; $\mathrm{PA}=$ protective antigen; Cap = capsule)

Lanes: (1) Bac+ Cap+ PA- (2) Bac+ Cap- PA(3) $\mathrm{Bac}+\mathrm{Cap}+\mathrm{PA}+$ (4) Bac+ Cap- PA- (5) Bac+ $\mathrm{Cap}+\mathrm{PA}+$ (6) Bac+ Cap- PA+ (7) Bac+ Cap+ $\mathrm{PA}+$ (8) Bac+ Cap- PA- (M) 50 bp DNA marker

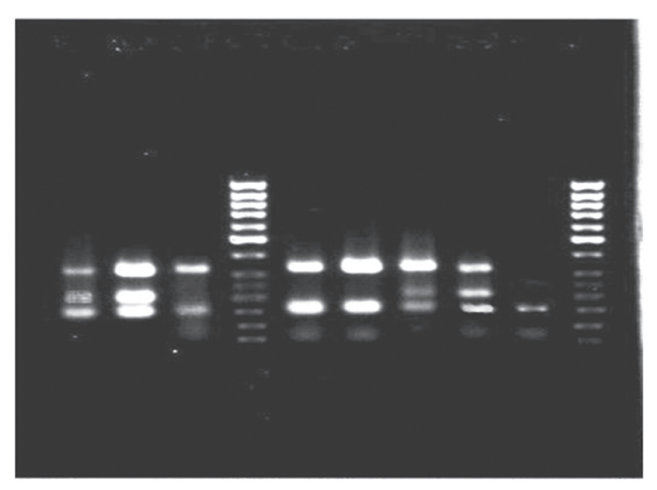

$\begin{array}{llllllllll}9 & 10 & 11 & M & 12 & 13 & 14 & 15 & 16 & M\end{array}$

Figure 2 Agarose gel electrophoresis of multiplex polymerase chain reaction products of Bacillus anthracis isolates (Bac $=B$. anthracis chromosome; $\mathrm{PA}=$ protective antigen; $\mathrm{Cap}=$ capsule)

Lanes: (9) Bac+ Cap+ PA+ (10) Bac+ Cap+ $\mathrm{PA}+$ (11) Bac+ Cap- PA+ (12) Bac+ Cap- PA+ (13) Bac+ Cap- PA+ (14) Bac+ Cap+ PA+ (15) $\mathrm{Bac}+\mathrm{Cap}+\mathrm{PA}+(16) \mathrm{Bac}+\mathrm{Cap}-\mathrm{PA}-(\mathrm{M}) 50$ bp DNA marker

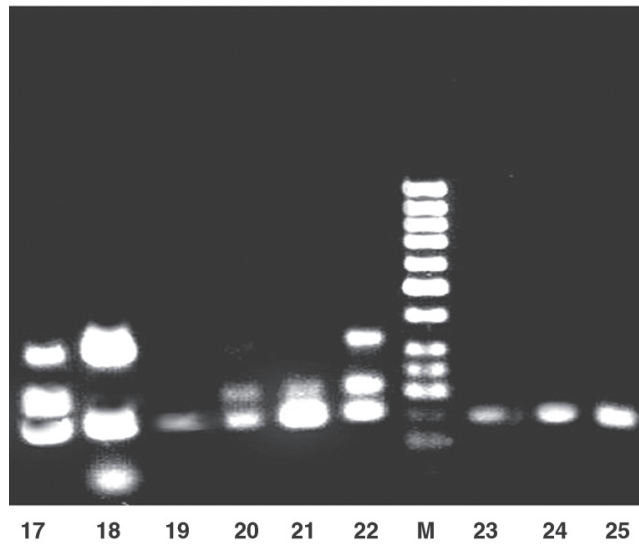

Figure 3 Agarose gel electrophoresis of multiplex polymerase chain reaction products of Bacillus anthracis isolates (Bac $=B$. anthracis chromosome; $\mathrm{PA}=$ protective antigen; Cap = capsule)

Lanes: (17) Bac+ Cap+ PA+ (18) Bac+ Cap$\mathrm{PA}+$ (19) Bac+ Cap- PA- (20) Bac+ Cap+ $\mathrm{PA}-$ (21) $\mathrm{Bac}+\mathrm{Cap}+\mathrm{PA}-$ (22) $\mathrm{Bac}+\mathrm{Cap}+\mathrm{PA}+$ (23) Bac+ Cap- PA- (24) Bac+ Cap- PA- (25) Bac+ Cap- PA- (M) 50 bp DNA marker

that lack both of these plasmids cannot be distinguished from other $B$. cereus group bacteria with classical analysis [5].

In this study, a reliable and rapid method for detection and characterization of $B$. anthracis was developed. With multiplex PCR, simultaneous amplification of specific genes on bacterial chromosome and 2 plasmids was performed. This assay is suitable for general identification of $B$. anthracis, because a strain lacking both pX01 and pX02 cannot be distinguished from other related species by microbiological analysis. This sensitive and rapid assay is a reliable test for confirmation and characterization of $B$. anthracis in laboratories.

It is important to keep in mind that studies of the epidemiology of $B$. anthracis are an important component in planning control 
and surveillance programmes for anthrax. We suggest that the multiplex PCR assay can be used for accurate diagnosis and analysis of toxic factors encoded by $B$. anthracis plasmids pX01 and pX02. This method reduces the time required for $B$. anthracis detection by about 3 hours in comparison with time-consuming classical microbiological and biochemical methods.

\section{References}

1. Mock $\mathrm{M}$ et al. Anthrax. Annual review of microbiology, 2001, 55:674-71.

2. Smith $\mathrm{H}$ et al. Observation on experimental anthrax. Nature, 1954, 173:869-70.

3. Patra $\mathrm{G}$ et al. Molecular characterization of Bacillus strains involved in outbreaks of anthrax in France in 1997. Journal of clinical microbiology, 1998, 35:3412-4.

4. Turnbull PCB. Guidelines for the surveillance and control of anthrax in human and animals, 3rd ed. Geneva, World Health Organization, 2001 (WHO/EMC/ ZDI/98.6).

5. Riedel S. Anthrax: a continuing concern in the era of bioterrorism. Baylor University Medical Center Proceedings, 2005, 18(3):234-43.

6. Henderson ID et al. Differentiation of Bacillus anthracis and other "Bacillus cereus group" bacteria using IS231-derived sequences. FEMS microbiology letters, 1995, 128:113-8.

7. Mikesell $P$ et al. Evidence for plasmid-mediated toxin production in Bacillus anthracis. Infection and immunity, 1983, 39:371-6.

8. Okinaka RT et al. Sequence and organization of pX01, the large Bacillus anthracis plasmid harboring the anthrax toxin genes. Journal of bacteriology, 1999, 181:650915.

9. Uchida et al. Association of the encapsulation of Bacillus anthracis with a 60 megadalton plasmid. Journal of general microbiology, 1985, 131:363-7.

10. Turnbull PCB. Definitive identification of Bacillus anthracis: a review. Journal of applied microbiology, 1999, 87:237-40.
11. Nakamura LK et al. Relationship of BacilIus subtilis clades associated with strains 168 and W23: a proposal for Bacillus subtilis subsp. subtilis subsp. nov. and $B a-$ cillus subtilis subsp. spizizenii subsp. nov. International journal of systematic bacteriology, 1999, 49:1211-5.

12. Dixon TC et al. Anthrax. New England journal of medicine, 1999, 341:815-6.

13. Quinn PJ, ed. Clinical veterinary microbiology. London, Wolfe Publishing, 1994.

14. Welkos SL, Keener TJ, Gibbs PH. Difference in susceptibility of inbred mice to Bacillus anthracis. Infection and immunity, 1986, 51:795-800.

15. Little SF, Knudson GB. Comparative efficacy of Bacillus anthracis live spore vaccine and protective antigen vaccine against anthrax in the guinea pig. Infection and immunity, 1986, 52:509-12.

16. Patra $\mathrm{G}$ et al. Isolation of a specific chromosome DNA sequence of Bacillus anthracis and its possible use in diagnosis. FEMS immunology and medical microbiology, 1996, 15:223-31.

17. Ramisse $\mathrm{V}$ et al. Identification and characterization of Bacillus anthracis by multiplex PCR analysis of sequences on plasmids pX01 and pX02 and chromosomal DNA. FEMS microbiology letter, 1996, 145:9-16.

18. Dragon DC et al. Detection of anthrax spores in endemic regions of northern Canada. Journal of applied microbiology, 2001, 91:435-41.

19. Ramachandran $S$ et al. Anthrax in Tiang and Transhumant cattle in South Sudan. Indian veterinary journal, 1988, 65:1074-9. 
20. Kaufmann AF et al. Observation on the occurrence of anthrax as related to soil type and rainfall. Proceedings of the international workshop on anthrax. Salisbury medical bulletin, 1990, 68:16-7.

21. Reif TC et al. Identification of capsuleforming Bacillus anthracis spores with the
PCR and a novel dual-probe hybridization format. Applied environmental microbiology, 1994, 171:722-30.

22. Makino SI et al. Direct detection of Bacillus anthracis DNA in animals by polymerase chain reaction. Journal of clinical microbiology, 1993, 31:547-51.

\section{Anthrax in humans and animals}

This fourth edition of the anthrax guidelines encompasses a systematic review of the extensive new scientific literature and relevant publications up to end 2007, including all the new information that emerged in the 3-4 years after the anthrax letter events.

This updated edition provides information on the disease and its importance, its etiology and ecology, and offers guidance on the detection, diagnostic, epidemiology, disinfection and decontamination, treatment and prophylaxis procedures, as well as control and surveillance processes for anthrax in humans and animals.

With two rounds of a rigorous peer-review process, it is a relevant source of information for the management of anthrax in humans and animals.

This publication is in press and will be in print shortly. Further information about WHO publications can be found at: http://www.who.int/ bookorders/anglais/home 1 .jsp?sesslan $=1$ 